\title{
Production lessening analysis of manufacturing unit in India: Lean Six Sigma perspective
}

\author{
Pankaj Kumar $^{\mathrm{a}}$, Mahipal Singh ${ }^{\mathrm{a}^{*}}$ and Gurpreet Singh Phull ${ }^{\mathrm{a}}$
}

${ }^{a}$ School of Mechanical Engineering, Lovely Professional University, Punjab, India

\begin{tabular}{|c|c|}
\hline CHR O N I L E & A B S T R A C T \\
\hline $\begin{array}{l}\text { Article history: } \\
\text { Received: March } 82019 \\
\text { Received in revised format: } \\
\text { April } 22019 \\
\text { Accepted: April } 22019 \\
\text { Available online: } \\
\text { April } 42019 \\
\text { Keywords: } \\
\text { Lean Six Sigma } \\
\text { DMAIC } \\
\text { Cause and Effect Diagram } \\
\text { Automotive manufacturing in- } \\
\text { dustry }\end{array}$ & $\begin{array}{l}\text { Lean Six Sigma is systematic and excellent operation management approach aimed to en- } \\
\text { hance overall production through the elimination of waste and improve customer satisfac- } \\
\text { tion. In the present case study, automobile part manufacturing unit has been selected and } \\
\text { found } 22 \% \text { wastage in manufacturing steps resulting reduction in production. The primary } \\
\text { objective of this research is to find the main reasons of production wastage and recommend } \\
\text { corresponding remedies to counter the wastage reasons. For this purpose, Lean Six Sigma } \\
\text { approach with the help of DMAIC methodology is implemented to observe and examine } \\
\text { different root causes of the frame lugs production losses and rejection problems. The result } \\
\text { reveals that the movement of material and employee are critical issues for wastage of re- } \\
\text { sources, ultimately affecting production of industry. Lastly, the possible solutions are to be } \\
\text { advised to tackling these issues. The successful execution of the proposed solutions show } \\
7 \% \text { growth in the production of the component which saves annually INR } 15,64,056 \text {. }\end{array}$ \\
\hline
\end{tabular}

\section{Introduction}

Manufacturing industries play an important role in strengthening India's economy (Singla et al., 2019). Many countries of the world are promoting their manufacturing sectors and are achieving success in developing their countries. India is also moving ahead in the list of those industrialized countries. It is possible due to the development of Indian industries that today India has become a developing country, whereas earlier it was included in the category of under-developed country (Raj et al., 2019). Manufacturing and industrial sectors give strong support to the economy. Manufacturing sector is mainly divided into three sectors; automotive industries, micro small medium enterprises (MSME) and heavy industries (Sharifi \& Zhang, 1999). Automotive and heavy industries are large corporations and they are having adequate resources for development. But there is still a need to improve MSMEs sector. In manufacturing sector, there is a wide scope for deployment of LSS in MSMEs in India because till now it is not fully explored in Indian context. The implementation of Lean Six Sigma strategy provides better results in manufacturing sectors (Singh \& Rathi, 2018). Lean Six Sigma is formed by combining both Lean and Six Sigma methodologies together. Where Lean's work is to reduce and remove eight major types of defects, at the same time 
the work of Six Sigma is to reduce variations in the product and to increase the quality of production processes (Chaurasia et al., 2019). Also Lean aims to attain continuous flow by building a linkage between procedure and process steps while Six Sigma gives attention to minimize process and operations variation.

In this study, problem has been identified through tools of Lean in DMAIC Six Sigma approach. The first step is to identify root cause of production declining in selected manufacturing company using fishbone diagram. The last Six months data has been collected related to main root causes of each department and analyze the weightage of each problem through brainstorming sessions with their concerns employees. Then the roadmap of root causes responsible for production declining in automobile part manufacturing unit has been prepared and suggested the solutions using Lean Six Sigma to improve the production of unit.

\section{Related Work}

The literature has been observed from the viewpoint of Lean and Six Sigma studies. Thomas et al. (2008) designed and applied a merged LSS methodology in manufacturing sector. In order to achieve significant development in company's cost, delivery and product quality, a simple yet extremely effective LSS model is designed, developed and implemented in this study. With the increasing competition in the markets, firms also need to enhance the quality of their products so that their products retain their hold in the market (Raja Sreedharam et al., 2018). Jeyaraman and Teo (2010) constructed a structured LSS framework based on DMAIC methodology. Raman and Basavaraj (2019) provided case study in which Six Sigma DMAIC methodology used to point out and examine different major reasons of the capacitors declining issues, which affect the works of the industry and propose solutions to face with it. Gandhi et al. (2019) provided a case study of casting cylinder blocks industry in which rejection rate of cylinder blocks is approximately $31 \%$ and after that this rejection rate was reduced using DMAIC methodology of Six Sigma. Ani, et al. (2016) utilized DMAIC approach of Six Sigma and used quality tools for solving the quality issues in automotive parts manufacturing environment and identified the suitable effective and essential tools that are based on DMAIC model. This case study was conducted in a bicycle component manufacturing industry and with the implementation of LSS in this industry enhanced the production of frame lugs. In this study, we use a DMAIC approach for analysing the causes for production loss and rejection of the components and implemented LSS for improvement in MSMEs. We also analysed the effect of the causes that impact on the production. Furthermore, suitable suggestions are provided for enhancing the production of unit and particular industry implemented them.

\section{Methodology}

\subsection{Define}

This is the starting phase of the Lean Six Sigma (LSS) methodology. In this phase a Project Charter is created that prepares plans for better processes and helps to understand the requirements of the customers. In this crucial phase, the team prepares better projects for leadership of the organization. This phase focuses on a problem that impacts the customers, ratifying the case is a priority and will have serious effect. Goals that organization want to achieve and the process maps are also defined in this phase. Stakeholder investigation starts in this Phase as well and the team revisits this key group during the project to confirm that others are active in enhancing the process.

\subsection{Measure}

This phase is used to measure the performance of the processes such as how the process presently works, make an idea to gather the data, confirm the data is genuine, collect the baseline data and update the project charter. Measurement is very much important during the whole period of the 
project. The task of collecting data by the team is started and specially focusing on the process, as well as what the clients care about is also measured. This means that initially two things are given special attention, improving quality and reducing lead time. In this way this phase refines the definition of the measurement and determines a strong and good baseline of current performance or process.

\subsection{Analyze}

There is often less attention devoted to the analyze phase, as a result without analysis, team reaches to solutions without understanding the real reasons of the problems. The outcome is that solutions are implemented by such teams, but no problem can be solved. Time is wasted due to such unsuccessful attempts, use of resources increases, arises more variations and, often chances to generate new problems also increase. It is mandatory for the ideal teams to brainstorm the possible root causes, create new ideas as to why such problems are coming and try to work on these ideas and then accept or reject their ideas. Both process and data are analyzed during verification and this must be accomplished before implementing the suggestions. So the essence of this phase is nearly scrutinize the process, graphically show the data, scrutinize for what might be causing the problems and verifies the causes of the problem.

\subsection{Improve}

As soon as the project teams find out the root causes, the process of developing the solutions is started. In this phase team selects the practical solutions, brainstorm solutions that might fix the problems, change pilot processes and develops maps of processes that are based on different solutions, implement solutions and in the last collect the data to ensure there is a quantitative advancement. Structural improvement efforts lead to higher and better solutions that are better than the previous ones and customers feel better in their own experiences.

\subsection{Control}

After fixing the problem of the process, this phase is selected by the teams to continue to improve and maintain the profit. In this phase the team is focused on making such plans which can be monitored to measure the success of the process and if the performance is declining then the response plan can be developed. After implementing all these phases, the team assigns the responsibility of continuing and maintenance of the plans to the process owner.

\section{Case Study}

This section describes the details of LSS framework for the case of automobile part manufacturing in small scale industry.

\subsection{Industry details}

The case organization manufacturer produces components of bicycle and this organization is located in the northern India. There are several manufacturers in this region producing bicycles and their components and supply them in other states. The case organization produces a bicycle component named frame lugs, whose work is to join the tubes together and strengthens the bicycle structure. Cold Rolled and Cooling (CRC) sheets are used for making this component. Here, the current manufacturing process of this automobile product has been studied and implemented the Lean Six Sigma framework for reducing rejection/faulty product during production and aims to be increased production of the industry. 


\subsection{Define phase}

\subsubsection{Problem definition}

Based on feedback from industry owner and workers, a meeting of experts and team members was organized to identify work flaws in the production. In the meeting, many defects were found in the production system of the bicycle component manufacturing industry. Team members found many defects during inspection, which were related to welding, pressing machine, product dimensions and movement of work-piece. The main motive is to find out the root causes of these defects and to minimize them from product and production system. In this context, the author used this tool to clearly define them actual problem undergoing on motion of work-piece.

\subsubsection{Process Flow chart}

All the manufacturing operations for bicycle component are apparent as shown in Fig. 1 using a flowchart which makes it easy to understand.
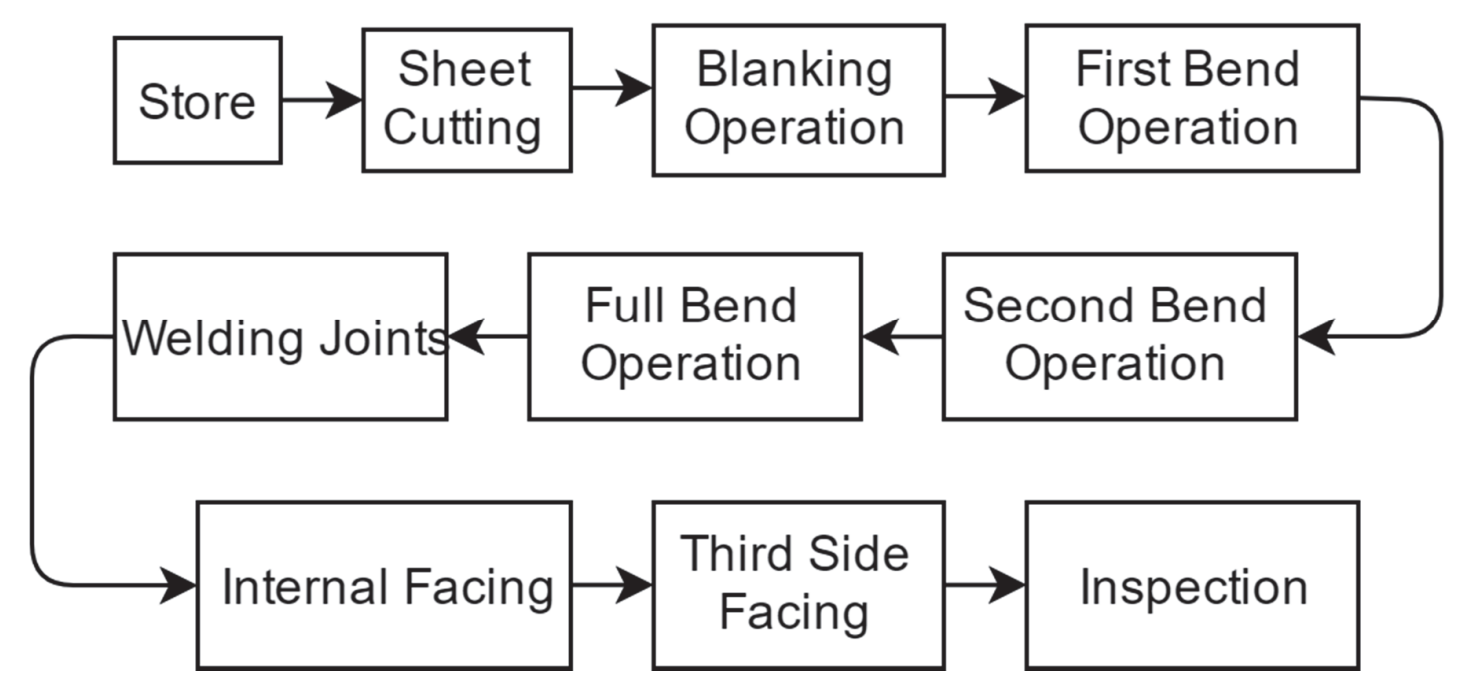

Fig. 1. Process flow chart of the frame lugs

\subsubsection{Current process map}

A current map of the present work has been prepared for the present scenario of the production system of the industry so that it can be helped to improve. A map of the current process can be developed only by properly studying the entire workflow process of the production system and for this create a proper graph of the material move via each workstation. The data needed for building the present state map are number of workers, cycle time and total available time.

\subsubsection{SIPOC chart}

SIPOC is a tool that summarized in table format and helps in the improvement of various processes by indicating complete manufacturing process of component from beginning to end. In this context, chart for bicycle component is developed to show the process from starting to end for clear visualization. The evolved SIPOC chart is shown in Table 1. 
Table 1

SIPOC chart

\begin{tabular}{lllll}
\hline Supplier & Input & Process & Output & Customer \\
\hline $\mathbf{X}$ & Take orders from distributors & Scrutiny of raw ma- & Bicycle & A \\
$\mathbf{Y}$ & Receiving raw material from & terials (CRC sheets) & component & B \\
$\mathbf{Z}$ & suppliers & Follow all processes & (Frame & C \\
& & (Which are shown in & lugs) & \\
& & flow diagram) & \\
& Scrutiny of finished & \\
& component & \\
& Dispatch to distribu- \\
& tor location as per & \\
& order & \\
& & & \\
& &
\end{tabular}

\subsection{Measure phase}

\subsubsection{Data collection}

In the time data collection, those data are collected which can make the image of the current state map. After monitoring the ongoing work on various process stations and interacting with the machine operators of industry, required data is collected. To organize and record data properly standard time has been taken for the various processes such as total number workers, cycle time and the total available time. The data collected from the case industry are shown in Table 2.

Table 2

Time Data Collection

\begin{tabular}{|c|c|c|c|c|c|c|c|c|c|c|c|}
\hline & 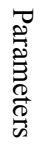 & 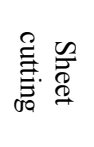 & 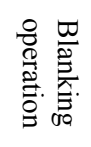 & 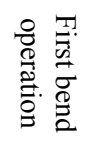 & 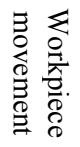 & 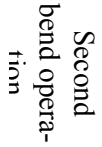 & 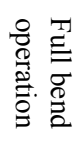 & 实: & 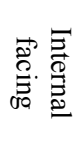 & 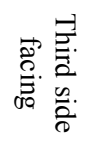 & 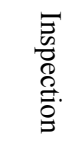 \\
\hline Cycle time (sec) & & 180 & 600 & 2.5 & 30 & 3 & 4.5 & 10 & 5 & 3 & 30 \\
\hline No. of operators & & 1 & 1 & 1 & 1 & 1 & 1 & 1 & 1 & 1 & 1 \\
\hline Availability(min) & & 480 & 480 & 480 & 480 & 480 & 480 & 480 & 480 & 480 & 480 \\
\hline
\end{tabular}

Total production of frame lugs in one month is 240,000 and rejection rate is $4.3 \%$ because of these rejection nearly 7,200 components are rejected every month. Therefore actual production of the industry is approximately 232,000 .

\subsubsection{Activity categorization}

Activity categorization is a process in which activities are defined on the basis of required (adding value in the process) and non-required (not adding any value in the process) processes. Activity categorization, based on the required value-adding activities and non-required value-adding activities, has been done for the bicycle component manufacturing line. The required value-adding activities include changeover time, machining time, and non-required value-adding activities are calculated by the subtraction between lead time and required value-adding time (Raman \& Basavaraj, 2019). The purpose of categorization of activities is to calculate time of required value-added and non-value added processes. The value-added and non-value-added activities are shown in Table 3. 
Table 3

Value-added and non-value-added activities

\begin{tabular}{cll}
\hline Serial No. & Process & $\begin{array}{l}\text { Value-added (VA)/ } \\
\text { non-value-added (NVA) }\end{array}$ \\
\hline 1. & Sheet cutting & VA \\
2. & Blanking operation & VA \\
3. & First bend operation & VA \\
4. & Movement of work-piece & NVA \\
5. & Second bend operation & VA \\
6. & Full bend operation & VA \\
7. & Welding joints & VA \\
8. & Internal facing & VA \\
9. & Third side facing & VA \\
10. & Inspection at each stage & NVA \\
\hline
\end{tabular}

\subsection{Analyse phase}

\subsubsection{Cause-and-effect diagram}

The primary goal of the all team members is to remove non-value-added activities and minimize the total defects from the process of bicycle component manufacturing line. The objective of causeand-effect diagram is to scrutinize the root of the defects occurring in product and evaluate the factual origin of defect from which they arisen. Past one month data is gathered from the bicycle component manufacturing industry, and all the defects that occur in a bicycle component manufacturing line are shown in Table 4 and based on this data, cause-and-effect diagram is also drawn and shown in Fig. 2.

\section{Table 4}

Defects and their contribution to total production

\begin{tabular}{lccc} 
Defects & $\begin{array}{c}\text { Defected components } \\
\text { (figure) }\end{array}$ & Weight age (\%) & $\begin{array}{c}\text { Cumulative } \\
(\%)\end{array}$ \\
\hline Setting scrap & 360 & 5 & 3 \\
Scrap due to vendor & 216 & 3 & 8 \\
Faulty steps & 864 & 12 & 20 \\
Blanking scrap & 648 & 9 & 29 \\
Incomplete fusion & 1008 & 14 & 43 \\
Unskilled worker & 792 & 11 & 54 \\
Cracks in welding & 720 & 10 & 64 \\
Improper facing & 144 & 2 & 66 \\
Inaccurate sheet cutting & 288 & 4 & 70 \\
Improper component dimensions & 360 & 5 & 75 \\
Bending scrap & 648 & 9 & 84 \\
Porosity in welding & 1152 & 16 & 100 \\
\hline
\end{tabular}




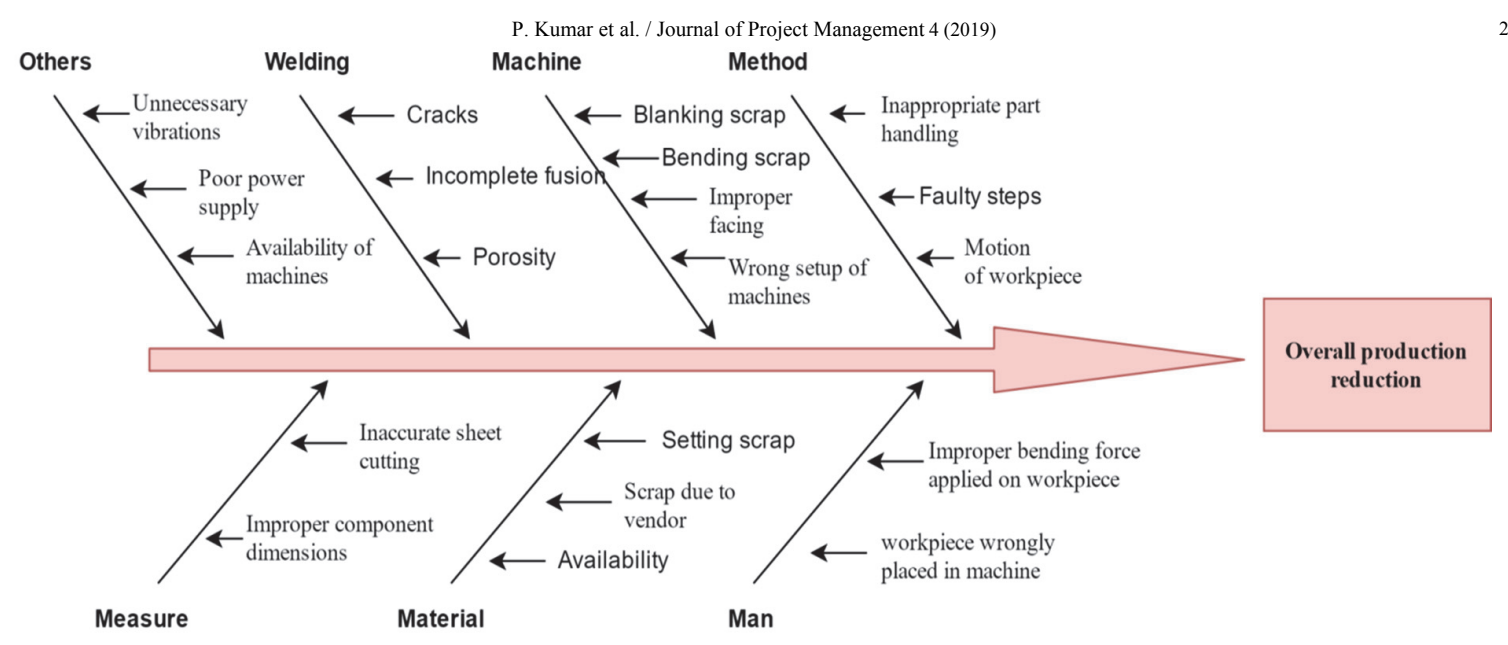

Fig. 2. Cause-and-effect diagram

After calculating and analysing the whole process time and cause-and-effect diagram of bicycle manufacturing component, we analysed and found different defects and causes, influencing the manufacturing process. These defects and causes are the results of lower productivity and rejection of the components. We found that in every 15 minutes there is a work-piece movement of 30 seconds, and in an hour it is about 2 minute. Therefore in an eight hours working shift 16 minutes are wasted on the movement of work-piece. These 16 minutes causes approximately $3 \%$ production loss in the bicycle manufacturing component industry, it means 3\% losses are due to rejection and $3 \%$ losses are due to unnecessary motion of the work-piece. If we can minimize this unnecessary work-piece movement then company utilizes this time in manufacturing the components and the production would be increased by $3.4 \%$ automatically.

\section{Table 5}

Analysis of root cause

\begin{tabular}{ccc}
\hline Root cause & Weight age \% & Production Loss Fig. \\
\hline Method & 53 & 8141 \\
Welding & 17 & 2611 \\
Man & 10 & 1536 \\
Machine & 7 & 1075 \\
Material & 6 & 922 \\
Measure & 4 & 614 \\
\hline
\end{tabular}

\subsubsection{Pareto chart}

All the data collected have been shown above (Refer Table 5) and with the help of those figures, we have created the Pareto chart. With the help of this chart, we can see the frequent root causes and easily focus on these root causes and offer suggestions of possible solutions to face them. From this chart we can see that Methods, Welding and Man giving a considerable contribution and hence it is necessary to pay attention on reducing them. If we focus on these 3 main causes and avail major resources for minimizing them then there is a possibility of decreasing $80 \%$ of the problems that are due to the $40 \%$ of the causes. 


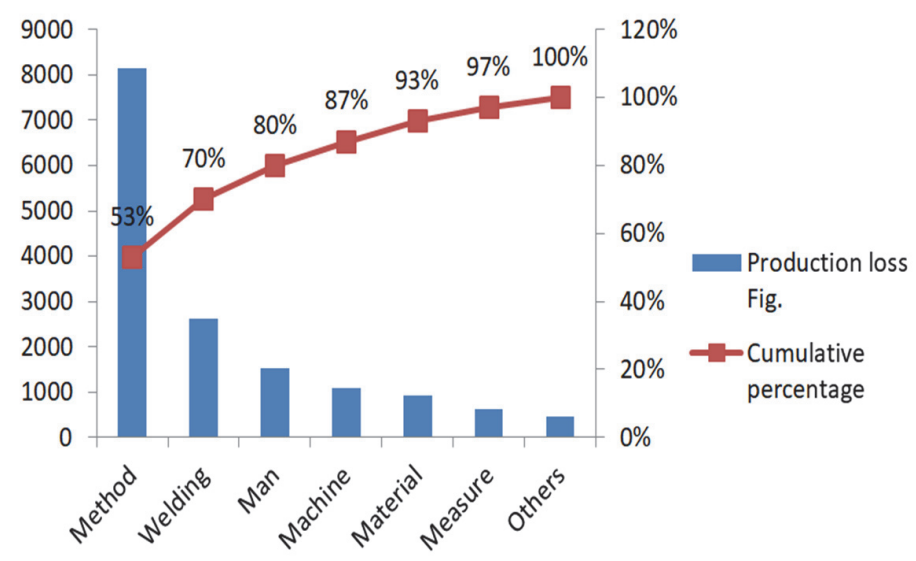

Fig. 3. Pareto chart

\subsection{Improve Phase}

A number of possible solutions have been suggested after closely investigating all the possible root causes, which help in the manufacturing industry to increase production and reduce losses. The solutions are given in Table 6.

\section{Table 6}

The proposed solutions

\begin{tabular}{|c|c|c|c|}
\hline $\begin{array}{l}\text { Root } \\
\text { cause }\end{array}$ & $\begin{array}{c}\text { Weigh } \\
\text { age }\end{array}$ & Causes \& effect & Proposed solution \\
\hline Method & $53 \%$ & $\begin{array}{ll}\text { 1. Unnecessary mo- } \\
\text { tion of work } \\
\text { piece } \\
\text { 2. Faulty steps } \\
\text { 3. Inappropriate } \\
\text { Part handling }\end{array}$ & $\begin{array}{l}\text { 1. Analyze the unnecessary motion and control as much as possible } \\
\text { 2. Before doing any new operation talk to the supervisor if any doubt } \\
\text { related to operation then clear it first } \\
\text { 3. Flow the work-piece fast through workstations so that time should } \\
\text { be save }\end{array}$ \\
\hline Welding & $17 \%$ & $\begin{array}{ll}\text { 1. } & \text { Cracks } \\
\text { 2. } & \text { Porosity } \\
\text { 3. Incomplete fu- } & \text { sion }\end{array}$ & $\begin{array}{l}\text { 1. The worker should be enough trained for welding process. } \\
\text { 2. Maintain the exact spray operation. } \\
\text { 3. Keep the proper welding machine setup before the execution of } \\
\text { the operation } \\
\text { 4. preserve exact gap between work-piece and the welding machine }\end{array}$ \\
\hline Man & $10 \%$ & $\begin{array}{l}\text { 1. Improper bend- } \\
\text { ing force applied } \\
\text { on work-piece } \\
\text { 2. Work piece } \\
\text { wrongly placed } \\
\text { in machine }\end{array}$ & $\begin{array}{l}\text { 1. Same force that required for bending should be applied on all } \\
\text { work-piece } \\
\text { 2. Don't talk or see anywhere during placing the work-piece into the } \\
\text { machine } \\
\text { 3. Always give the job to the worker who is suitable of that opera- } \\
\text { tion }\end{array}$ \\
\hline Machine & $7 \%$ & $\begin{array}{ll}\text { 1. } & \text { Blanking scrap } \\
\text { 2. } & \text { Bending scrap } \\
\text { 3. Improper facing } \\
\text { 4. } \\
\text { Wrong setup of } \\
\text { machines }\end{array}$ & $\begin{array}{l}\text { 1. Do repairing of the machine on proper time interval } \\
\text { 2. Do oiling in the machine on daily basis } \\
\text { 3. Do sharp the edges of the machine facing tool after particular time } \\
\text { 4. Examine the machine setup if there is any need to change for im- } \\
\text { provement then do it }\end{array}$ \\
\hline Material & $6 \%$ & $\begin{array}{l}\text { 1. Material availa- } \\
\text { bility } \\
\text { 2. Setting scrap } \\
\text { 3. Scrap due to ven- } \\
\text { dor }\end{array}$ & $\begin{array}{l}\text { 1. Always check availability of the raw material before taking a } \\
\text { large order of the products } \\
\text { 2. Order the raw material only from the trusted suppliers } \\
\text { 3. Unload the raw material from the expert workers and keep it in } \\
\text { safe and dry place }\end{array}$ \\
\hline Measure & $4 \%$ & $\begin{array}{l}\text { 1. Inaccurate sheet } \\
\text { cutting } \\
\text { 2. Improper compo- } \\
\text { nent dimensions }\end{array}$ & $\begin{array}{l}\text { 1. Properly measured the dimensions of the sheet before cutting it } \\
\text { 2. Use sharp blade shearing machine for exact and smooth sheet cut- } \\
\text { ting }\end{array}$ \\
\hline Others & $3 \%$ & $\begin{array}{l}\text { 1. Availability of } \\
\text { machines } \\
\text { 2. Poor power sup- } \\
\text { ply } \\
\text { 3. Unnecessary vi- } \\
\text { brations }\end{array}$ & $\begin{array}{l}\text { 1. Use each and every machine for proper utilization of the machine } \\
\text { 2. Use generators to run machines when power supply problem oc- } \\
\text { curs } \\
\text { 3. Set the machines in ground floor and maintain proper level so that } \\
\text { avoided unnecessary vibrations }\end{array}$ \\
\hline
\end{tabular}


The primary goal of this qualitative research study was to find out the causes of the defects of frame lugs within the manufacturing process and capacity losses due to defects and unnecessary operations. Thus, the aim of this case study was not only to figure out the defects but also to sort out the causes of production loss in the bicycle component manufacturing industry. After organized brainstorming activities and discussion with team members all feasible solutions provides to the bicycle component manufacturing industry. To develop the long lasting solution a new work map was created, standardized and would be executed in the industry. Along with it, the process that would be executed will examine until it became a regular practice.

\section{Conclusion}

The main objective of this case study was to provide a list of causes for production losses and the causes for the rejection of frame lugs in manufacturing industry and suggest most feasible solutions to reduce them. This study was essential to enhance the productivity and decrease in the defects. In the starting a process map was noted to look the areas of enhancement. Cause and effect diagram helps to further examine the major causes. Past Six months report helped in finding out the participation of each major cause. Pareto Chart assisted in shrinking down the major causes further. The aim of the study was to figure out the root causes for the loss in production in frame lugs during manufacturing. This case study is still going on to reduce the defects that we found in this paper. This research also confers the region for developing the techniques for solving the problem of frame lugs production losses.

\section{References}

Ani, M. N. C., Azid, I. A., \& Kamarudin, S. (2016). Solving quality issues in automotive component manufacturing environment by utilizing six sigma DMAIC approach and quality tools.

Chaurasia, B., Garg, D., \& Agarwal, A. (2019). Lean Six Sigma approach: a strategy to enhance performance of first through time and scrap reduction in an automotive industry. International Journal of Business Excellence, 17(1), 42-57.

Gandhi, S., Sachdeva, A., \& Gupta, A. (2019). Reduction of rejection of cylinder blocks in a casting unit: A six sigma DMAIC perspective. Journal of Project Management, 4(2), 81-96.

Jeyaraman, K., \& Kee Teo, L. (2010). A conceptual framework for critical success factors of lean Six Sigma: Implementation on the performance of electronic manufacturing service industry. International Journal of Lean Six Sigma, 1(3), 191-215.

Raj, A., Kuznetsov, A., Arun, T., \& Kuznetsova, O. (2019). How different are corporate social responsibility motives in a developing country? Insights from a study of Indian agribusiness firms. Thunderbird International Business Review, 61(2), 255-265.

Raja Sreedharan, V., Raju, R., Rajkanth, R., \& Nagaraj, M. (2018). An empirical assessment of Lean Six Sigma Awareness in manufacturing industries: construct development and validation. Total Quality Management \& Business Excellence, 29(5-6), 686-703.

Raman, R., \& Basavaraj, Y. (2019). Defect reduction in a capacitor manufacturing process through Six Sigma concept: A case study. Management Science Letters, 9(2), 253-260.

Sharifi, H., \& Zhang, Z. (1999). A methodology for achieving agility in manufacturing organisations: An introduction. International journal of production economics, 62(1-2), 7-22.

Singh, M., \& Rathi, R. (2018). A structured review of Lean Six Sigma in various industrial sectors. International Journal of Lean Six Sigma. https://doi.org/10.1108/IJLSS-03-2018-0018.

Singla, A., Ahuja, I. S., \& Sethi, A. S. (2019). An examination of effectiveness of technology push strategies for achieving sustainable development in manufacturing industries. Journal of Science and Technology Policy Management, 10(1), 73-101.

Swarnakar, V., \& Vinodh, S. (2016). Deploying Lean Six Sigma framework in an automotive component manufacturing organization. International Journal of Lean Six Sigma, 7(3), 267-293. 
Thomas, A., Barton, R., \& Chuke-Okafor, C. (2008). Applying lean six sigma in a small engineering company-a model for change. Journal of Manufacturing Technology Management, 20(1), 113129.

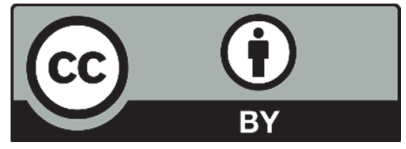

(C) 2018 by the authors; licensee Growing Science, Canada. This is an open access article distributed under the terms and conditions of the Creative Commons Attribution (CC-BY) license (http://creativecommons.org/licenses/by/4.0/). 